\title{
Development of an Orange Juice Surrogate for the Study of Dental Erosion
}

\author{
Tais SCARAMUCCI ${ }^{1}$ \\ Anderson T. HARA ${ }^{2}$ \\ Domenick T. ZERO² \\ Stella S. FERREIRA ${ }^{1}$ \\ Idalina $\mathrm{V}$. $\mathrm{AOKI}^{3}$ \\ Maria Angela P. SOBRAL ${ }^{1}$ \\ ${ }^{1}$ Department of Restorative Dentistry, Dental School, USP - University of São Paulo, São Paulo, SP, Brazil \\ ${ }^{2}$ Oral Health Research Institute, Department of Preventive and Community Dentistry, \\ Indiana University Dental School, Indianapolis, IN, USA \\ ${ }^{3}$ Department of Chemical Engineering, Polytechnic School, USP - University of São Paulo, São Paulo, SP, Brazil
}

\begin{abstract}
The aim of this study was to create a synthetic juice (SJ) to be used as a surrogate for natural orange juices in erosion studies, verifying its erosive potential. The SJ was formulated based on the chemical composition of orange juices from different locations. Forty enamel and 40 root dentin specimens were randomly assigned into 4 experimental groups $(n=10)$ : SJ; 1\% Citric Acid (CA); Minute Maid Original ${ }^{\circledR}(\mathrm{MM})$ and Florida Natural Original ${ }^{\circledR}(\mathrm{FN})$. The specimens were immersed in their respective solutions for $5 \mathrm{~min}, 6 \mathrm{x} /$ day for 5 days, in an erosion-remineralization cycling model. Enamel specimens were analyzed by surface Knoop microhardness and optical profilometry and dentin specimens only by optical profilometry. Outcomes were analyzed statistically by ANOVA followed by Tukey's test considering a significance level of 5\%. For enamel, the surface loss and microhardness changes found for MM and SJ groups were similar $(\mathrm{p}>0.05)$ and significantly lower $(\mathrm{p}<0.01)$ than those found in the CA group. For dentin, CA promoted significantly greater $(p<0.01)$ surface loss compared with all the other groups. No significant difference $(p>0.05)$ was observed in dentin surface loss between MM and SJ. In conclusion, CA was the most erosive solution, and SJ had a similar erosive potential to that of MM natural orange juice.
\end{abstract}

Key Words: Dental erosion, orange juice, profilometry, microhardness, citric acid.

\section{INTRODUCTION}

Dietary acids, such as citric, malic, lactic and phosphoric acids, have been related to the development of dental erosion $(1,2)$. Differences in their erosive potential are associated with the chemical properties and composition of the acidic solutions, including $\mathrm{pH}$ (3), titratable acidity (4), buffer capacity (5), chelating properties (6) and amounts of calcium, phosphates and fluoride (5).

Among those cited acids, special attention has been given to the citric acid (CA), since it is commonly found in citric fruits and juices (7). Due to its worldwide popularity, orange juice has been considered a suitable representative of citric juices for dental erosion studies and some studies have reported its erosive potential
$(8,9)$. However, its composition can vary according to the origin of the fruit. Thus, in an attempt to standardize and simplify laboratory studies, surrogates for orange juices and other citric fruit juices have been used consisting basically of CA solutions with concentrations ranging from 0.1 to $1 \%(\mathrm{w} / \mathrm{v})$ and $\mathrm{pH}$ adjusted usually from the natural values up to 3.8 , which is thought to be representative of commercial beverages and juices (1). This seems to be a common and widespread practice among investigators $(1,10-12)$. Although this has been accepted, there are differences in the softening promoted by a citric solution $(0.65 \%, \mathrm{pH} 3.6)$ and an orange juice with the same CA concentration (7), which means that the use of pure CA does not seem appropriate to simulate the clinical condition (13).

The erosive potential of a citric fruit juice is

Correspondence: Dra. Taís Scaramucci, Departamento de Dentística Restauradora, Faculdade de Odontologia, Universidade de São Paulo, USP, Avenida Professor Lineu Prestes, 2227, Cidade Universitária, 05508-000 São Paulo, SP, Brasil. Tel/Fax: +55-11-3091-7841. e-mail: tais.sca@usp.br 
not only related to $\mathrm{pH}$ and concentration of $\mathrm{CA}$, but also to the low degree of saturation in relation to both hydroxyapatite and fluorapatite (6), and the presence of citrate, a substance capable of chelating the calcium of saliva and teeth (14). These factors are important and can affect the erosive potential of a solution.

Thus, as much as has been recognized the importance of standardization in laboratory research, the currently available surrogates for orange juice might not serve as proper substitutes because they do not have minerals and other compounds that may influence the erosion process. Therefore, the objectives of this study were: 1 . to create a synthetic juice (SJ) based on the composition of natural orange juice, from different locations (15-17); 2. to verify if the erosive potential of the created SJ is similar to that of natural orange juice. The outcomes of this study may help defining better surrogates for orange juice for use in future dental erosion studies.

\section{MATERIAL AND METHODS}

\section{Experimental Design}

In the first phase of this study, a surrogate for orange juice was developed using compositional information of natural orange juices. In the second phase, the created synthetic formulation was compared in vitro with two commercial products in order to verify whether or not it adequately reproduced their erosive potentials. It was also compared with $1 \%$ CA solution ( $\mathrm{pH} 3.8$ ), commonly used as orange juice surrogate in previously published studies. A demineralization/remineralization study using enamel and root dentin was conducted. Surface microhardness change was assessed on enamel only, while surface loss was measured on both enamel and root dentin by optical profilometry.

\section{Testing Solutions}

The SJ composition was based on an average composition of natural orange juices made with oranges from different locations (15-17), with special attention to the mineral compounds. An average composition of the major chemical compounds was determined (Table 1), and the formula used for preparation of SJ was determined based on this information (Table 2). The $\mathrm{pH}$ of SJ was adjusted to 3.8 with $1 \mathrm{~N} \mathrm{NaOH}$. Two commercially available natural orange juices, Minute
Maid Original ${ }^{\circledR}(\mathrm{MM}$; The Coca-Cola Company, Atlanta, GA, USA) and Florida Natural Original ${ }^{\mathbb{}}$ (FN; Citrus World Inc., Lake Wales, FL, USA) were selected and purchased in sufficient amount for the whole study.

\section{Cycling Study}

This study was approved by the IUPUI/Clarian Institutional Review Board (process \#NS0911-07). Enamel and root dentin specimens (4 x 4 × $2 \mathrm{~mm}$ ) from human molars were used for this test. The crowns of the teeth were sectioned in hard-tissue microtome in order to obtain enamel and root dentin fragments. The fragments were ground flat with water-cooled abrasive discs (500-, 1200-, 2400- and 4000-grit $\mathrm{Al}_{2} \mathrm{O}_{3}$ papers; MD-Fuga, Struers Inc., Cleveland, OH, USA) and polished with polishing cloth and diamond suspension (1 $\mu \mathrm{m}$; Struers Inc.). The polished surface had tapes placed on, leaving exposed a central testing area of $4 \times 1 \mathrm{~mm}$.

Table 1. Average composition of natural orange juices.

\begin{tabular}{|c|c|c|}
\hline Elements & $\begin{array}{l}\text { Average quantity } \\
\qquad(\mathrm{mg} / \mathrm{L})\end{array}$ & Range (mg/L) \\
\hline Calcium & 86.95 & $80.3-100.00$ \\
\hline Iron & 3.99 & $0.61-9.24$ \\
\hline Magnesium & 131.65 & $107.50-155$ \\
\hline Phosphorus & 189.37 & $137.50-242.5$ \\
\hline Potassium & 1939.87 & $1575-2273.50$ \\
\hline Sodium & 50.50 & $3.075-176$ \\
\hline Zinc & 0.42 & $0.34-0.61$ \\
\hline Copper & 0.30 & $0.16-0.39$ \\
\hline Aluminum & 1.39 & $0.084-5.03$ \\
\hline Manganese & 0.36 & $0.19-0.625$ \\
\hline Bore & 1.24 & $1.07-1.50$ \\
\hline Barium & 0.22 & $0.047-0.47$ \\
\hline Rubidium & 2.00 & $0.55-4.56$ \\
\hline Strontium & 0.62 & $0.53-0.69$ \\
\hline Tin & 0.075 & $0.002-0.18$ \\
\hline Ascorbic acid & 500 & -- \\
\hline Citric acid & 7500 & -- \\
\hline Sucrose & 21000 & -- \\
\hline Glucose & 84000 & -- \\
\hline
\end{tabular}


Forty enamel specimens and 40 dentin specimens were randomly allocated into 4 experimental groups $(n=10)$, according to the four solutions under study: SJ, $1 \%$ $\mathrm{CA}, \mathrm{MM}$ and FN. Then, the specimens were subjected to an in vitro erosion cycling model. One study day comprised 6 erosion-remineralization cycles. In each cycle, specimens were immersed for $5 \mathrm{~min}(10 \mathrm{~mL} /$ specimen) in one of the test solutions and for $60 \mathrm{~min}$ $(10 \mathrm{~mL} / \mathrm{specimen})$ in artificial saliva. Specimens were rinsed in deionized water and dried between erosive and remineralization episodes. This phase of the study was conducted during 5 days, leading to a total of 30 cycles.

After cycling, the tapes were removed from the specimens and surface profile traces were performed. An area $2 \mathrm{~mm}$ long (X) x $1 \mathrm{~mm}$ wide (Y) was scanned with an optical profilometer (Proscan 200; Scantron, Venture Way, Tauton, UK). The length covered both treated area and reference surfaces. The step size was set at $0.01 \mathrm{~mm}$ and the number of steps at 2000 in the (X) axle; and at $0.05 \mathrm{~mm}$ and 20, respectively, in the (Y) axle. With the

Table 2. Recipe of synthetic juice.

\begin{tabular}{|c|c|c|}
\hline Compound & Quantity & Reagent used \\
\hline Citric Acid & $7.5 \mathrm{~g} / \mathrm{L}$ & Citric acid P.A. \\
\hline Ascorbic Acid & $0.5 \mathrm{~g} / \mathrm{L}$ & Ascorbic acid P.A. \\
\hline Sucrose & $21 \mathrm{~g} / \mathrm{L}$ & Sucrose P.A. \\
\hline Glucose & $84 \mathrm{~g} / \mathrm{L}$ & Glucose P.A. \\
\hline Magnesium & $1.10 \mathrm{~g} / \mathrm{L}$ & $\mathrm{MgCl}_{2} 6 \mathrm{H}_{2} \mathrm{O}$ \\
\hline Phosphorus & $1.64 \mathrm{~g} / \mathrm{L}$ & $\mathrm{Na}_{2} \mathrm{PO}_{4} \cdot 7 \mathrm{H}_{2} \mathrm{O}$ \\
\hline Potassium & $1.19 \mathrm{~g} / \mathrm{L}$ & $\mathrm{KCL}$ \\
\hline Calcium & $0.32 \mathrm{~g} / \mathrm{L}$ & $\mathrm{CaCl}_{2} \cdot 2 \mathrm{H}_{2} \mathrm{O}$ \\
\hline Sodium & $0.13 \mathrm{~g} / \mathrm{L}$ & $\mathrm{NaCl}$ \\
\hline Iron & $19.30 \mathrm{mg} / \mathrm{L}$ & $\mathrm{FeCl}_{3} \cdot 6 \mathrm{H}_{2} \mathrm{O}$ \\
\hline Zinc & $0.14 \mathrm{mg} / \mathrm{L}$ & $\mathrm{ZnCl}_{2}$ \\
\hline Copper & $1.20 \mathrm{mg} / \mathrm{L}$ & $\mathrm{CuSO}_{4} .5 \mathrm{H}_{2} \mathrm{O}$ \\
\hline Aluminum & $12.40 \mathrm{mg} / \mathrm{L}$ & $\mathrm{AlCl}_{3} \cdot 6 \mathrm{H}_{2} \mathrm{O}$ \\
\hline Manganese & $0.80 \mathrm{mg} / \mathrm{L}$ & $\mathrm{MnCl}_{2}$ \\
\hline Bore & $13.20 \mathrm{mg} / \mathrm{L}$ & $\mathrm{Na}_{2} \mathrm{~B}_{4} \mathrm{O}_{7} \cdot 10 \mathrm{H}_{2} \mathrm{O}$ \\
\hline Barium & $0.30 \mathrm{mg} / \mathrm{L}$ & $\mathrm{BaCl}_{2}$ \\
\hline Rubidium & $2.80 \mathrm{mg} / \mathrm{L}$ & $\mathrm{RbCl}$ \\
\hline Strontium & $1.90 \mathrm{mg} / \mathrm{L}$ & $\mathrm{SrCl}_{2} \cdot 6 \mathrm{H}_{2} \mathrm{O}$ \\
\hline Tin & $1.10 \mathrm{mg} / \mathrm{L}$ & $\mathrm{SnCl}_{2}$ \\
\hline
\end{tabular}

use of dedicated software, the depth of the treated area was calculated based on the subtraction of the average heath of the test area from the average height of the reference surfaces.

For enamel specimens, surface microhardness analysis was performed using Knoop diamond indenter (2100 B; Instron Corporation, Wilson Instruments, Norwood, MA, USA) with $50 \mathrm{~g}$ load for $15 \mathrm{~s}$. For this analysis, 6 indentations were made in the sound enamel ( 3 in each of the reference surfaces) and 3 indentations in the lesion area, with at least $100 \mu \mathrm{m}$ of distance between them. The means for reference and experimental areas were calculated and the difference between them was considered the surface microhardness change (SMC):

$\mathrm{SMC}=$ mean reference area - mean experimental area.

\section{Statistical Analysis}

Homoscedasticity and normal distribution of the data was checked by the Hartley and Shapiro-Wilks tests. Once these assumptions were satisfied, oneway ANOVA and Tukey's tests were carried out for comparisons among groups, for both response variables tested. The software SigmaPlot 11.0 (Systat Software Inc., Chicago, IL, USA) was used for the calculations, with significance level of $5 \%$.

\section{RESULTS}

Means and standard deviation (SD) of the profilometry and microhardness analysis are shown in Tables 3 and 4, respectively.

In dentin specimens, the CA solution promoted a greater surface loss in comparison with all the other groups ( $p<0.01)$. No significant difference was observed in the dentin surface loss between the MM and SJ groups ( $>0.05$ ). For enamel, surface loss and microhardness changes found for MM and SJ were very similar $(p<0.01)$ and significantly lower than that of the CA group ( $<<0.01)$.

\section{DISCUSSION}

It is well known that care should be taken when extrapolating the results of in vitro studies to in vivo conditions. This occurs mainly because it is not possible to mimic all the in vivo aspects in the laboratory. However, it is important to make the conditions of in 
vitro studies as close as possible to the clinical reality. CA solutions with different concentrations and $\mathrm{pH}$ have been used in many investigations as surrogates for erosive drinks. However, the present study demonstrated that $1 \% \mathrm{CA}(\mathrm{pH} 3.8)$ may not be the most suitable substitute for orange juice, despite having the same range of $\mathrm{pH}$ and titratable acidity (18).

For root dentin, the CA solution promoted a greater surface loss in comparison with all the other groups. No difference was observed between MM and SJ, which had less surface loss than the FN group. This result may be explained by the relatively lower $\mathrm{pH}$ found for the latter product (3.80vs. 3.70). For enamel, it seems that the surface loss found for MM and SJ groups were similar and different from the other groups. However, the surface loss values observed for MM and SJ were at or below the detection limit of the used evaluation method ( $0.5 \mu$ m of dental surface loss) (19). Therefore, the surface loss results for enamel demonstrated only that CA caused the most accentuated enamel loss, and that surface deposition occurred for the FN juice. The deposition layer, possibly composed by the organic components present in the juice, was detected in all specimens of that group. This layer made it impossible to accurately assess the surface loss (if any) by optical

Table 3. Means (SD) of surface loss (SL) for enamel and dentin (in $\mu \mathrm{m}$ ).

\begin{tabular}{lcc}
\hline Groups & SL Enamel & SL Dentin \\
\hline Citric acid & $-2.79( \pm 0.61)^{\mathrm{c}}$ & $-11.28( \pm 0.85)^{\mathrm{c}}$ \\
Synthetic juice & $-0.53( \pm 0.13)^{\mathrm{b}}$ & $-4.66( \pm 0.63)^{\mathrm{a}}$ \\
Minute Maid Original $^{\circledR}$ & $-0.28( \pm 0.15)^{\mathrm{b}}$ & $-5.07( \pm 0.71)^{\mathrm{a}}$ \\
Florida Natural Original $^{\circledR}$ & $0.77( \pm 0.39)^{\mathrm{a}}$ & $-7.11( \pm 1.63)^{\mathrm{b}}$ \\
\hline
\end{tabular}

Different superscript indicates significant difference $(\mathrm{p}<0.05)$ in columns. profilometry. As an additional analysis, the surface Knoop microhardness was measured and showed to be a more adequate evaluation method, for the testing solutions, in the erosion model adopted.

The surface microhardness changes found for $\mathrm{MM}$ and SJ groups were similar between each other and lower than the changes found for the other groups. This data confirmed what was suggested by the surface loss data. However, it was not clear whether or not SJ can be an adequate surrogate for FN or not. The surface microhardness change for FN was numerically similar to the CA and more aggressive than both $\mathrm{MM}$ and SJ. While it was expected to observe higher erosive effect for the FN mainly due to its lower $\mathrm{pH}$, the magnitude of the differences in surface microhardness was unexpected. This may be explained by the limitations of the surface microhardness method for testing some of the groups, especially FN, which presented a deposition layer on the enamel surface detected by profilometry (20). The presence of this layer could have caused indentations to be potentially larger - due to the softness of the layer - than in the MM and SJ groups, possibly leading to relatively larger indentations and lower hardness values. On the other hand, the considerable surface loss for the CA group probably affected the SMC values observed.

The surface analyzed in the microhardness test was not the most superficial enamel layer, which had been lost, but the exposed sub-superficial layer. In that case, it is possible to speculate that FN was probably less erosive than CA, since it did not cause any measureable surface loss. Therefore, in the present study, it was not possible to conclude whether or not the proposed SJ and the $1 \% \mathrm{CA}(\mathrm{pH} 3.8)$ were adequate surrogates for $\mathrm{FN}$.

Orange juice was chosen for this study because of its recognized erosive potential (8) and due to the fact that its composition has a great variation according to the origin of the orange. For instance, the average calcium concentration in an Australian orange juice was measured to be approximately $80.3 \mathrm{mg} / \mathrm{L}$ (16), while the concentration of this ion in a Brazilian orange juice was approximately $100 \mathrm{mg} / \mathrm{L}$ (15). Calcium concentration in an acid drink is particularly important because this ion has a role in the demineralization/remineralization process (21). Previous investigations reported that the addition of approximately $20 \mathrm{mg} / \mathrm{L}$ of calcium to an orange juice was able to reduce enamel loss (10). Thus, these variations

Different superscript indicates significant difference $(\mathrm{p}<0.05)$ in columns. 
found in orange juices from different origins could exert a great influence on its erosive potential when used in erosion studies. Even though this makes it difficult to find a single standard similar to all juices, we targeted for a formulation that would be representative of most orange juices. This was the rationale behind creating a synthetic formula using the average mineral composition of orange juices made with oranges from Australia, Brazil and Florida (15-17).

The formulation of SJ combined most of the detected minerals in the previous elemental analysis. This was done in order to closely represent the natural juice. Some of the elements may not be relevant or may be present in irrelevant concentrations. If this is in fact verified, more simple solutions can be formulated. The sources for the mineral elements were chemical reagents, chosen according to their solubility product, $\mathrm{k}_{\mathrm{sp}}$. Reagents with higher solubility $\left(>\mathrm{k}_{\mathrm{sp}}\right)$ were preferred. The $\mathrm{pH}$ of the juice was adjusted to be at 3.8, for standardization purposes, but it was in the $\mathrm{pH}$ range of the natural juices tested. It is important to mention that the organic phase of the juice, mainly lipids and proteins, were not considered in this synthetic formulation. They may also be relevant for defining the erosive potential of the synthetic solution and this has been further investigated in other projects.

In conclusion, it was observed that $\mathrm{CA}$ is not a good substitute for natural orange juice in erosion studies. The proposed synthetic formulation was proven to be an adequate surrogate for orange juice, but this was confirmed for only one of the orange juices tested in the present study due to methodological limitations related to the other natural juice. Further validation using more clinically relevant erosion models should be conducted as well as comparisons with other orange juices.

\section{RESUMO}

O objetivo deste estudo foi criar um suco sintético (SJ) para ser usado como substituto do suco de laranja natural em estudos de erosão dental, verificando o seu potencial erosivo. O SJ foi formulado com base na composição química de sucos de laranja de diferentes locais. Quarenta espécimes de esmalte e 40 de dentina radicular foram aleatoriamente alocados em 4 grupos experimentais $(\mathrm{n}=10)$ : SJ; 1\% Citric acid (CA); Minute Maid Original ${ }^{\circledR}(\mathrm{MM})$ e Florida Natural Original ${ }^{\circledR}(\mathrm{FN})$. Os espécimes foram imersos nas suas respectivas soluções por $5 \mathrm{~min}, 6 \mathrm{x} /$ dia por 5 dias, em um modelo de ciclagem de erosão-remineralização. Os espécimes de esmalte foram analisados por microdureza de superfície Knoop e perfilometria ótica, enquanto que os espécimes de dentina foram analisados somente por perfilometria. Os resultados foram analisados estatisticamente com o teste de
ANOVA, seguido pelo teste de Tukey, considerando um nível de significância de 5\%. Para o esmalte, a perda superficial e as alterações de microdureza encontradas para os grupos MM e SJ foram similares $(p>0,05)$ e significantemente menores $(p<0,01)$ do que as encontradas para o grupo CA. Para dentina, CA promoveu significantemente $(\mathrm{p}<0,01)$ a maior perda de superfície quando comparada aos outros grupos. Não foram encontradas diferenças significantes $(\mathrm{p}>0,05)$ entre a perda de superfície de dentina dos grupos MM e SJ. Concluiu-se que CA foi a solução mais erosiva e SJ apresentou um potencial erosivo semelhante ao do suco de laranja natural MM.

\section{ACKNOWLEDGEMENTS}

The authors would like to thank Coordination of Training of Higher Education Graduate (CAPES) for the scholarship (\#BEX 1719092) and the Indiana University School of Dentistry/Professional Development Program for the financial support.

\section{REFERENCES}

1. Hughes JA, West NX, Parker DM, Van Den Braak MH, Addy M Effects of $\mathrm{pH}$ and concentration of citric, malic and lactic acids on enamel, in vitro. J Dent 2000;28:147-152.

2. Attin T, Becker K, Hannig C, Buchalla W, Hilgers R. Method to detect minimal amounts of calcium dissolved in acidic solutions. Caries Res 2005;39:432-436.

3. Lussi A, Jaggi T, Scharer S. The influence of different factors on in vitro enamel erosion. Caries Res 1993;27:387-393.

4. Hanning C, Hamkens A, Becker K, Attin R, Attin T. Erosive effects of different acids on bovine enamel: release of calcium and phosphate in vitro. Arch Oral Biol 2005;50:541-552.

5. Larsen MJ, Nyvad B. Enamel erosion by some soft drinks and orange juices relative to their $\mathrm{pH}$, buffering effect and contents of calcium phosphate. Caries Res 1999;33:81-87.

6. Lussi A, Jaeggi T. Chemical Factors. Mon Oral Sci 2006;20:77-87.

7. Voronets J, Lussi A. Thickness of softened human enamel removed by toothbrush abrasion: an in vitro study. Clin Oral Invest 2010;14:251-256.

8. West NX, Maxwell A, Hughes JA, Parker DM, Newcombe RG, Addy M. A method to measure clinical erosion: the effect of orange juice consumption on erosion of enamel. J Dent 1998;26:329-335.

9. West NX, Hughes JA, Parker DM, Newcombe RG, Addy M Development and evaluation of a low erosive blackcurrant drink. 2. Comparison with a conventional blackcurrant juice drink and orange juice. J Dent 1999;27:341-344.

10. Attin T, Meyer K, Hellwig E, Buchalla W, Lennon AM. Effect of mineral supplements to citric acid on enamel erosion. Arch Oral Biol 2003;48:753-759.

11. Hara AT, Ando M, Cury JA, Serra MC, González-Cabezas C, Zero DT. Influence of the organic matrix on root dentine erosion by citric acid. Caries Res 2005;39:134-138.

12. Eisenburger M. Degree of mineral loss in softened human enamel after acid erosion measured by chemical analysis. J Dent 2009;37:491-494.

13. Wegehaupt FJ, Gunthart N, Sener B, Attin T. Prevention of erosive/ abrasive enamel wear due to orange juice modified with dietary supplements. Oral Dis 2011;17:508-514.

14. Meurman JH, Rytomaa I, Kari K, Laakso T, Murtomaa H. Salivary $\mathrm{pH}$ and glucose after consuming various beverages, including sugar-containing drinks. Caries Res 1987;21:353-359. 
15. Mchard JA, Foulk SJ, Winefordner JD. A comparison of trace element contents of Florida and Brazil orange juice. J Agric Food Chem 1979;27:1326-1328.

16. Simpkins WA, Louie H, Wub M, Harrison M, Goldberg D. Trace elements in Australian orange juice and other products. Food Chem 2000;71:423-433.

17. Fili SP, Oliveira E, Oliveira P. On line- digestion in a focused microwave-assisted oven for elements determination in orange juice by inductively coupled plasma optical emission spectrometry. J Braz Chem Soc 2003;14:435-441.

18. Shellis RP, Ganss C, Ren Y, Zero DT, Lussi A. Methodology and models in erosion research: discussion and conclusions. Caries Res 2011;45:69-77.
19. Hara AT, Zero DT. Analysis of the erosive potential of calciumcontaining acidic beverages. Eur J Oral Sci 2008;116:60-65.

20. Schlueter N, Hara A, Shellis RP, Ganss C. Methods for the measurement and characterization of erosion in enamel and dentine. Caries Res 2011;45:13-23.

21. Lussi A, Schlueter N, Rakhmatullina E, Ganss C. Dental erosion - an overview with emphasis on chemical and histopathological aspects. Caries Res 2011;45:2-12.

Received October 15, 2010 Accepted September 2, 2011 